\title{
PERBANDINGAN TIGA PENDEKATAN GEOSTATISTIK UNTUK MEMODELKAN KETIDAKPASTIAN DALAM ESTIMASI SUMBERDAYA TIMAH DAN MINERAL IKUTAN TIMAH PADA ENDAPAN ALUVIAL
}

\author{
1)Raymond Kosher Sianturi', 2)Mohamad Nur Heriawan, ${ }^{2}$ Syafrizal, ${ }^{3)}$ Cahyo Okta Ardian, \\ ${ }^{3}$ Satyogroho Dian Amertho, dan ${ }^{3 /}$ /chwan Azwardi Lubis \\ 1)Program Studi Magister Rekayasa Pertambangan, Fakultas Teknik Pertambangan dan Perminyakan, \\ Institut Teknologi Bandung \\ 2)Kelompok Keahlian Eksplorasi Sumberdaya Bumi, Fakultas Teknik Pertambangan dan Perminyakan, \\ Institut Teknologi Bandung \\ 3)PT Timah Tbk., Provinsi Kep. Bangka Belitung
}

Artikel masuk : 26-03-2021, Artikel diterima : 31-03-2021

\section{Kata kunci: \\ geostatistik, timah, mineral ikutan timah, ketidakpastian sumberdaya, endapan aluvial.}

Keywords:

geostatistics, tin, lead-byminerals, resource uncertainty, alluvial deposits.

\section{ABSTRAK}

Blok C merupakan salah satu blok endapan aluvial di Pulau Bangka yang memiliki prospek timah dan mineral ikutan timah seperti ilmenite, rutile, anatase, zircon, dan monazite. Endapan aluvial umumnya memiliki variabilitas yang tinggi sehingga faktor ketidakpastian akan sumberdaya timah dan mineral ikutan timah juga tinggi. Pada penelitian ini dilakukan perbandingan 3 (tiga) pendekatan geostatistik untuk memodelkan ketidakpastian sumberdaya dengan studi kasus endapan aluvial di Blok C Pulau Bangka. Metode Global Estimation Variance (GEV) untuk mengetahui variabilitas global sedangkan Sequential Gaussian Simulation (SGS) dan Discrete Gaussian Model (DGM) untuk mengetahui variabilitas lokal. Hasil metode GEV dibandingkan dengan metode SGS dan metode DGM. Hasil perbandingan GEV dan SGS menunjukkan bahwa hasil GEV cenderung less confidence dibandingkan hasil SGS. Less confidence pada hasil GEV disebabkan efek proporsional di daerah penelitian. Hasil perbandingan SGS dan DGM menunjukkan pola yang hampir sama untuk Sn (timah) dan ilmenite+rutile+anatase serta pola yang cukup berbeda untuk zircon. Perbedaan ini disebabkan oleh pemusatan data dari metode DGM. Selain itu, mayoritas nilai minimum hasil DGM lebih besar daripada nilai minimum hasil SGS dan nilai maksimum hasil DGM lebih kecil daripada nilai maksimum hasil SGS. Hal ini disebabkan oleh change of support coefficient $(r)$ yang mempengaruhi fungsi dari transformasi.

${ }^{*}$ Corresponding author: raymondksss30@gmail.com

Doi : https://doi.org/10.36986/impj.v2i2.34 


\section{ABSTRACT}

Block $C$ is one of the alluvial deposit blocks on Bangka Island which has the prospect of tin and lead-associated minerals such as ilmenite, rutile, anatase, zircon, and monazite. Alluvial deposits generally have high variability so that the uncertainty factor for tin resources and lead associated minerals is also high. In this study, a comparison of 3 (three) geostatistical approaches to modeling resource uncertainty was carried out with a case study of alluvial deposits in Block C of Bangka Island. The Global Estimation Variance (GEV) method is to determine global variability, while the Sequential Gaussian Simulation (SGS) and Discrete Gaussian Model (DGM) are to determine local variability. The results of the GEV method were compared with the SGS method and the DGM method. The comparison between GEV and SGS shows that the GEV results tend to be less confident than the SGS results. Less confidence in GEV results due to proportional effects in the study area. The comparative results of SGS and DGM show almost the same pattern for Sn (tin) and ilmenite + rutile + anatase and quite different patterns for zircon. This difference is caused by the centralization of data from the DGM method. In addition, the majority of the minimum value of the DGM result is greater than the minimum value of the SGS result and the maximum value of the DGM result is smaller than the maximum value of the SGS result. This is caused by the change of support coefficient (r) which affects the function of the transformation.Keyword: geostatistics, tin, tin associated minerals, resource uncertainty, allluvial deposit.

\section{PENDAHULUAN}

Salah satu wilayah yang dilewati oleh sabuk timah asia tenggara yang merupakan intrusi granit yang kaya akan mineralisasi timah adalah Pulau Bangka (Schwartz dkk., 1995; Ng dkk., 2017; Purwadi dkk., 2020). Selain kaya akan mineralisasi timah pada mineral cassiterite, granit juga merupakan pembawa untuk mineral-mineral seperti ilmenite, rutile, anatase, zircon, monazite dan xenotime yang merupakan mineral asosiasi pada endapan timah aluvial. Mineral-mineral ini biasanya disebut sebagai mineral ikutan timah (MIT) (Syafrizal dkk., 2019). Cassiterite, ilmenite, rutile, zircon, monazite, dan xenotime dapat terendapkan sebagai mineral berat pada endapan aluvial (placer) karena memiliki density yang tinggi, tahan terhadap pelapukan kimia, dan mechanical durability (Evans, 1993).

Endapan aluvial terkenal sulit untuk dilakukan estimasi atau memperkirakan kadar dan tonase (Dixon, 1979). Hal ini dikarenakan endapan aluvial umumnya memiliki variabilitas yang tinggi sehingga faktor ketidakpastian akan sumberdaya juga tinggi. Cornah dkk., (2013) melakukan penelitian dengan membandingkan 3 (tiga) metode geostatistik yang dapat digunakan untuk memodelkan ketidakpastian sumberdaya pada endapan batubara. 3 (tiga) metode geostatistik tersebut adalah Global
Estimation Variance (GEV), Sequential Gaussian Simulation (SGS), dan Discrete Gaussian Model (DGM). GEV dapat digunakan untuk mengetahui variabilitas global, sedangkan SGS dan DGM dapat digunakan untuk mengetahui variabilitas lokal di daerah penelitian.

GEV adalah konsep operasional dengan mengkarakteristikan error yang berkaitan dengan pola pengambilan sampel tertentu dan geometri yang akan diestimasi (Bertoli dkk., 2013). Penggunaan GEV telah dilakukan oleh beberapa peneliti pada endapan batubara (Heriawan dkk., 2020; Geovariances, 2016; Bertoli dkk., 2013; Cornah dkk., 2013). GEV menggunakan varians ekstensi untuk menghitung error ketika suatu blok diestimasi dengan menggunakan satu sampel yang terletak di tengah blok (Cornah dkk., 2013).

SGS dan DGM merupakan metode dari conditional simulation. Conditional simulation dapat menghasilkan hasil yang lebih kompleks yang merepresentasikan distribusi kadar sebenarnya, sedangkan pada estimasi hasil yang didapatkan lebih halus (smoother) yang merepresentasikan distribusi hasil estimasi (Sinclair dan Blackwell, 2002). SGS cocok digunakan untuk data yang kontinu atau yang telah ditransformasi ke distribusi normal (gaussian) (Madenoglu dkk., 2020). Beberapa penelitian yang menggunaan SGS untuk menganalisis ketidakpastian telah dilakukan oleh Heriawan dan Koike (2008) pada endapan batubara dan Paithankar dan Chatterjee (2017) pada deposit tembaga. DGM adalah change of support model yang paling populer untuk mengestimasi distribusi block grade (Chiles, 2014). Dalam praktik menggunakan metode DGM, nilai data yang telah ditransformasi menjadi distribusi gaussian (standar normal) dipusatkan ke blok yang akan diestimasi (Cornah dkk., 2013). Deraisme dkk. (2008) menggunakan DGM untuk block simulation dengan menggunakan data tembaga dan arsen.

Pada penelitian ini, 3 (tiga) metode geostatistik untuk memodelkan ketidakpastian sumberdaya yaitu GEV, SGS, dan DGM dilakukan dan dibandingkan pada endapan aluvial dengan studi kasus di Blok $C$ yang memiliki keterdapatan timah dan mineral ikutan timah pada endapan aluvial. Hasil dari GEV berupa nilai relative error akan dibandingkan dengan hasil dari SGS berupa nilai relative error atau Global Standardised Estimation Precision (GSEP). Untuk hasil dari DGM, nilai minimum dan maksimum hasil simulasi pada setiap blok akan dibandingkan dengan nilai minimum dan maksimum hasil simulasi dengan menggunakan SGS. 


\section{METODOLOGI PENELITIAN}

\section{Data}

Data yang digunakan pada penelitian ini adalah data sekunder berupa data pemboran di Blok $\mathrm{C}$ di Pulau Bangka. Data sekunder yang digunakan adalah data 2D yang didapatkan dari PT Timah Tbk. yang berjumlah 24 titik bor dan berisi informasi koordinat titik bor dan kadar yang dinotasikan dengan TDH (timah dihitung) dari Sn (timah) dan MIT yang meliputi ilmenite+rutile+anatase, zircon, monazite, dan xenotime. Koordinat titik bor dari data sekunder yang diperoleh telah ditransformasi ke dalam koordinat lokal. Koordinat ini selanjutnya di-plot untuk melihat sebaran titik bor dari data sekunder. Spasi bor rata-rata di daerah penelitian adalah \pm 30 $\mathrm{m}$. Untuk sebaran titik bor di daerah penelitian dapat lihat pada Gambar 1.

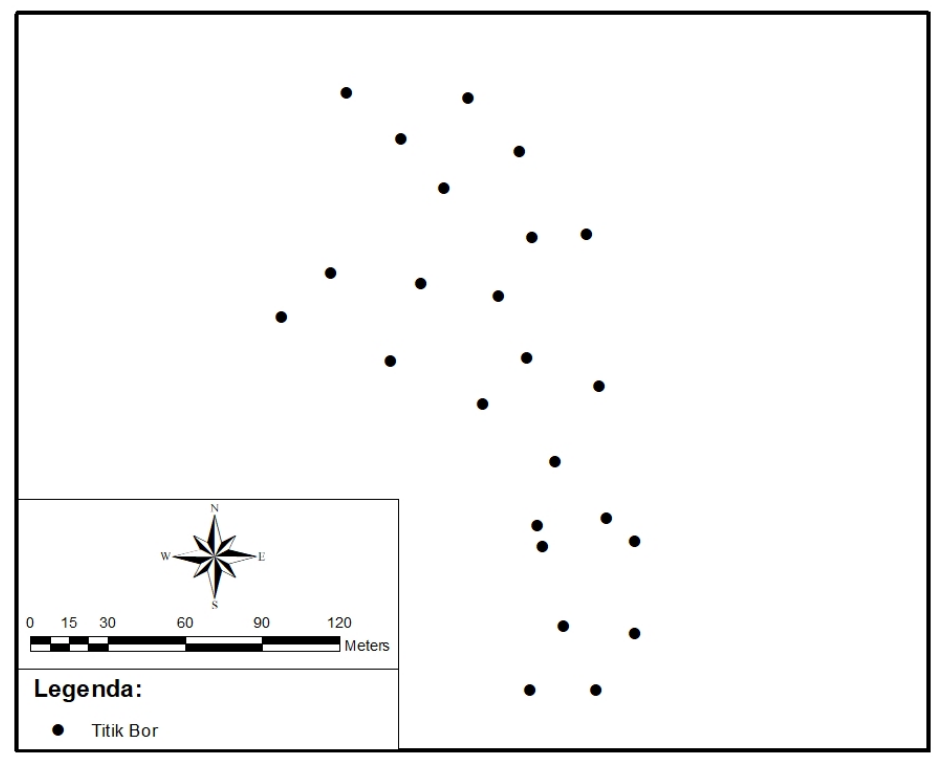

Gambar 1. Peta sebaran titik bor di Blok C

Data tersebut selanjutnya dilakukan analisis statistik univariate dengan tujuan untuk mengetahui parameter-parameter atau karakteristik populasi dari data untuk masing-masing komoditas/mineral. Analisis statistik univariate dilakukan dengan melihat nilai mean, median, standar deviasi, coefficient of variation (CoV), minimum, maximum, dan count dari data kadar atau TDH Sn (timah) dan MIT. Untuk analisis statistik univariate dapat dilihat pada Tabel 1.

Tabel 1. Parameter statistik dari kadar atau TDH Sn (timah) dan MIT

\begin{tabular}{cccccc}
\hline Parameter Statistik & Sn (timah) & IIm+Rut+Ana & Zircon & Monazite & Xenotime \\
\hline Mean & 0.0359 & 0.1161 & 0.0303 & 0.0002 & 0 \\
Median & 0.0274 & 0.1024 & 0.0169 & 0.0000 & 0 \\
Standard Deviation & 0.0323 & 0.0893 & 0.0291 & 0.0004 & 0 \\
Coefficient of Variation & 0.8989 & 0.7697 & 0.9606 & 2.7929 & - \\
Minimum & 0 & 0.0283 & 0.0008 & 0 & 0 \\
Maximum & 0.1021 & 0.4474 & 0.1072 & 0.0016 & 0 \\
Count & 24 & 24 & 24 & 24 & 24 \\
\hline
\end{tabular}

Selain itu, data tersebut juga dilakukan penentuan pencilan. Penentuan pencilan dilakukan dengan menggunakan nilai CoV. Jika data memiliki nilai CoV $\geq 1.5$, data tersebut dianggap memiliki pencilan yang harus dikeluarkan. Data yang memiliki CoV $<1.5$, data tersebut tidak dilakukan penentuan pencilan. 
Untuk komoditas/mineral yang hanya terdapat pada beberapa data bor saja dan yang tidak terdapat pada data bor seperti monazite (4 lubang bor) dan xenotime (0 lubang bor) tidak dilakukan analisis lebih lanjut. Data-data yang akan dianalisis lebih lanjut adalah data kadar atau TDH dari Sn (timah), ilmenite+rutile+anatase, dan zircon.

\section{Global Estimation Variance (GEV)}

Sebelum melakukan GEV, terlebih dahulu dilakukan pembuatan variogram untuk data-data yang akan dianalisis. Variogram digunakan untuk melihat variabilitas antara 2 data yang dipisahkan oleh jarak. Secara matematis, variogram dinyatakan dengan persamaan sebagai berikut:

$$
\gamma(h)=\frac{\sum_{i=1}^{n}[Z(X i)-Z(X i+h)]^{2}}{2 N(h)}
$$

Pada persamaan di atas menunjukkan bahwa $\gamma(h)$ merupakan variogram eksperimental, $Z(X i)$ adalah nilai pada lokasi $(X i), Z(X i+h)$ adalah nilai pada lokasi $(X I)$ yang dipisahkan oleh jarak $(h)$.

Untuk variogram yang digunakan adalah variogram omnidirectional dengan arah $\mathrm{N} 0^{\circ} \mathrm{E}$ dan toleransi sudut $90^{\circ}$. Proses fitting variogram menggunakan model spherical dan dilakukan untuk mengetahui parameter variogram seperti nugget effect $\left(C_{0}\right)$, daerah pengaruh/range $(a)$, dan sill $\left(C_{0}+C_{1}\right)$. Untuk parameter variogram hasil fitting dapat dilihat pada Tabel 2.

Tabel 2. Parameter variogram untuk masing-masing komoditas/mineral

\begin{tabular}{cccc}
\hline Parameter Variogram & Sn (timah) & IIm+Rut+Ana & Zircon \\
\hline$C_{0}$ & 0.0001 & 0.0055 & 0.00043 \\
$C_{1}$ & 0.00097 & 0.0024 & 0.00047 \\
$a(\mathrm{~m})$ & 70 & 45 & 60 \\
\hline
\end{tabular}

varians estimasi dan jumlah blok pada suatu luasan

GEV digunakan untuk mencari nilai relative error secara global di daerah penelitian. Salah satu parameter yang digunakan pada metode GEV adalah varians estimasi. Varians estimasi dihitung dengan menggunakan parameter-parameter variogram. Perhitungan varians estimasi dilakukan pada blok dengan ukuran yang sama seperti spasi bor rata-rata. Sebelum dilakukan perhitungan varians estimasi, blok dengan ukuran yang sama seperti spasi bor rata-rata didiskritisasi dengan ukuran $5 \times 5$, sehingga blok tersebut memiliki 25 titik yang tersusun secara teratur. Untuk menghitung varians estimasi digunakan rumus sebagai berikut:

$$
\sigma_{e}^{2}=2 \bar{\gamma}(S, V)-\bar{\gamma}(V, V)-\bar{\gamma}(S, S)
$$

Pada persamaan di atas menunjukkan bahwa $\overline{\sigma^{2}}$ adalah varians estimasi, $\overline{\bar{\gamma}(S, V)}$ adalah nilai variogram rata-rata titik ke blok, $\overline{\gamma(V, V)}$ adalah nilai variogram rata-rata blok ke blok, dan $\overline{\gamma(S, S)}$ adalah nilai variogram titik ke titik.

Nilai varians estimasi yang telah diperoleh pada masing-masing komoditas/mineral digunakan untuk menghitung GEV. Perhitungan GEV untuk masingmasing komoditas/mineral menggunakan nilai daerah di daerah penelitian. Untuk menghitung GEV digunakan rumus sebagai berikut:

$$
G E V=\frac{\sigma^{2} e}{N}
$$

Pada persamaan di atas menunjukkan bahwa GEV adalah Global Estimation Variance, $\overline{\sigma^{2}}{ }_{e}$ adalah varians estimasi, dan $\sqrt{N}$ adalah jumlah blok di suatu luasan daerah atau area.

Nilai GEV yang telah diperoleh pada masing-masing komoditas/mineral digunakan untuk menghitung nilai relative error. Perhitungan nilai relative error untuk masing-masing komoditas/mineral menggunakan GEV dan nilai rata-rata (mean) dari masing-masing komoditas/mineral. Dengan asumsi tingkat kepercayaan $95 \%$, nilai relative error dihitung dengan menggunakan rumus sebagai berikut:

relative error $=\frac{ \pm 2 \sqrt{G E V}}{\bar{Z}} \times 100 \%$

Pada persamaan di atas menunjukkan bahwa relative error adalah nilai relative error, GEV adalah Global Estimation Variance, dan $\bar{Z}$ adalah nilai ratarata (mean).

Hasil perhitungan nilai relative error dengan menggunakan GEV untuk masing-masing 
komoditas/mineral akan dibandingkan dengan hasil nilai relative error (GSEP) dengan menggunakan SGS.

\section{Sequential Gaussian Simulation (SGS)}

Sebelum dilakukan simulasi dengan menggunakan metode SGS, data-data terlebih dahulu ditransformasi menjadi distribusi gaussian (standar normal). Data yang telah ditransformasi dilakukan pengecekan kembali dengan melihat histogram, nilai mean, dan variance. Apabila data yang telah ditrasnformasi menunjukkan histogram telah terdistribusi normal, nilai mean mendekati 0 , dan variance mendekati 1 , maka data tersebut dapat dilakukan simulasi dengan menggunakan SGS.

Data yang telah ditransformasi menjadi distribusi gaussian dan memenuhi syarat untuk proses simulasi, selanjutnya dilakukan pembuatan variogram atau point gaussian semivariogram dengan arah omnidirectional. Proses fitting variogram menggunakan model spherical. Untuk point gaussian semivariogram dari masing-masing komoditas/mineral dapat dilihat pada Gambar 2.
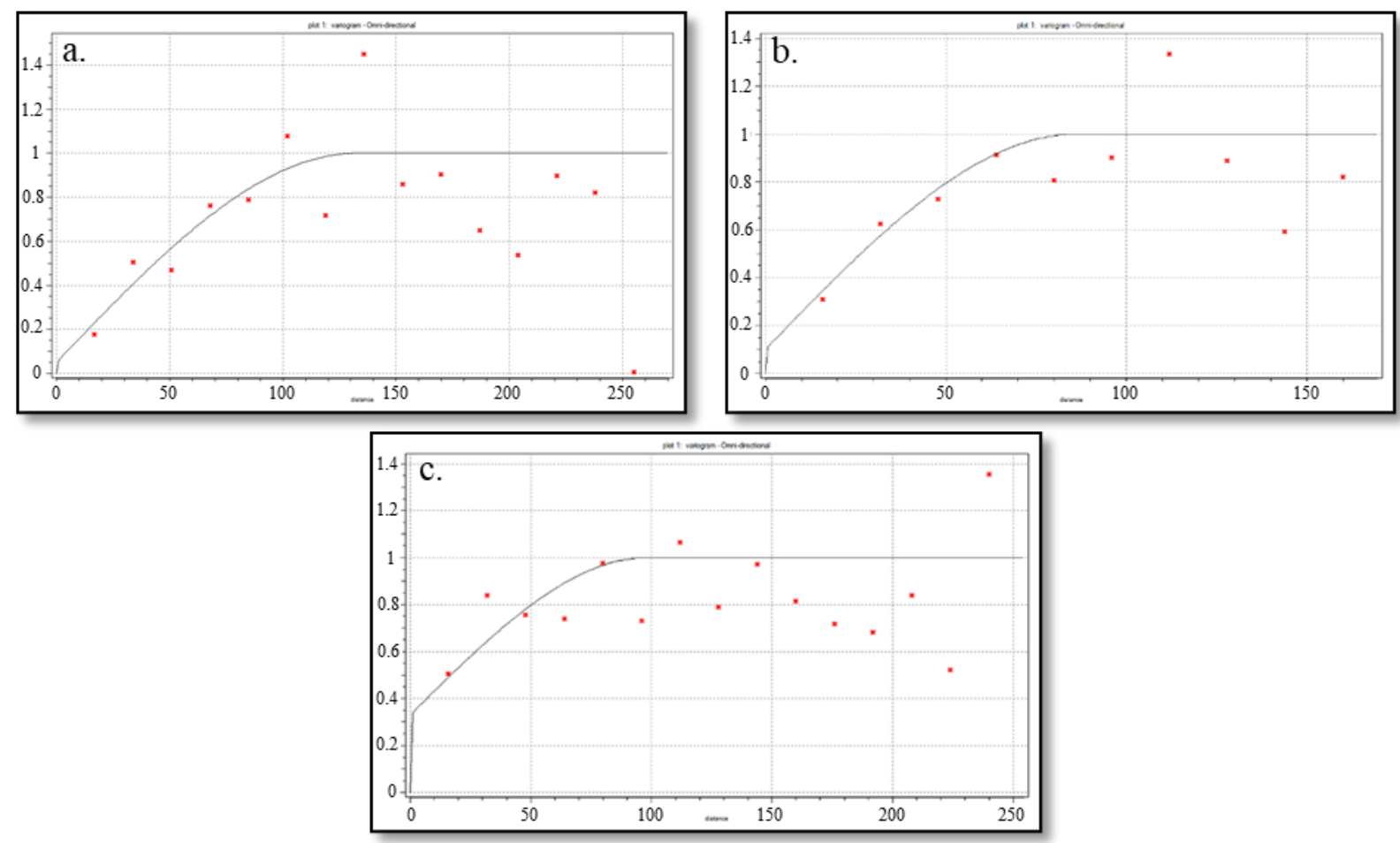

Gambar 2. Point gaussian semivariogram untuk: (a). Sn (timah), (b). IImenite+Rutile+Anatase, dan (c). Zircon

Selanjutnya dilakukan proses simulasi dengan
menggunakan SGS pada masing-masing komoditas/mineral di daerah penelitian. Ukuran blok simulasi dibuat sesuai dengan spasi bor rata-rata di daerah penelitian. Jumlah realisasi yang dilakukan sebanyak 100 realisasi. Tipe kriging yang digunakan adalah Simple Kriging (SK). Hasil simulasi yang berupa 100 realisasi pada masing-masing blok simulasi, selanjutnya dilakukan back transform agar kembali seperti data awal. Hasil simulasi yang telah di-back transform selanjutnya dicari nilai minimum dan maksimum dari 100 realisasi pada setiap blok simulasi untuk dibandingkan dengan hasil simulasi dengan menggunakan DGM.

Hasil simulasi dengan menggunakan SGS juga akan dilakukan perhitungan Global Standardised
Estimation Precision (GSEP) atau nilai relative error di setiap blok simulasi. Perhitungan GSEP mengacu pada Cornah dkk. (2013) dengan menggunakan nilai residual. Sebelum menghitung nilai residual, nilai rata-rata (mean) dari setiap realisasi dihitung terlebih dahulu. Setelah itu, dihitung nilai residual dengan cara menghitung selisih antara hasil realisasi pada setiap blok dengan nilai rata-rata (mean) yang telah dihitung sebelumnya. Sehingga didapatkan 100 residual pada setiap bloknya. Dari 100 residual pada setiap blok, dilakukan perhitungan variance dan standar deviasi sehingga setiap blok memiliki 1 nilai standar deviasi. Selanjutnya dilakukan perhitungan nilai standar deviasi estimasi dengan menggunakan standar deviasi dan jumlah titik bor di daerah penelitian. Untuk menghitung standar deviasi estimasi menggunakan rumus sebagai berikut: 
$\sigma_{E}=\frac{S D}{N}$

Pada persamaan di atas menunjukkan bahwa $\sigma_{E}$ adalah standar deviasi estimasi, $S D$ adalah standar deviasi, dan $N$ adalah jumlah titik bor di daerah penelitian.

Nilai standar deviasi estimasi yang telah diperoleh di setiap blok simulasi pada masing-masing komoditas/mineral selanjutnya dilakukan perhitungan untuk menentukan GSEP. Perhitungan GSEP menggunakan nilai standar deviasi estimasi dan nilai rata-rata (mean) dari data awal. Dengan asumsi tingkat kepercayaan 95\%, GSEP dihitung dengan menggunakan rumus sebagai berikut:

$$
G S E P= \pm 2 \frac{\overline{\sigma E}}{\bar{Z}}
$$

Pada persamaan di atas menunjukkan bahwa GSEP adalah Global Standardised Estimation Precision, $\sigma_{E}$ adalah standar deviasi estimasi, dan $\overline{\bar{Z}}$ adalah nilai rata-rata (mean) dari data awal.

Nilai GSEP atau relative error yang telah diperoleh pada setiap blok simulasi selanjutnya dicari nilai minimum, nilai rata-rata (mean), dan maksimum untuk masing-masing komoditas/mineral di daerah penelitian. Nilai minimum, mean, dan maksimum dari GSEP atau relative error hasil simulasi dengan menggunakan SGS akan dibandingkan dengan nilai relative error hasil GEV.

\section{Discrete Gaussian Model (DGM)}

Simulasi dengan DGM menggunakan program matlab dari Emery (2009). Program matlab ini terdiri dari beberapa subroutine atau script untuk melakukan simulasi. Sebelum melakukan simulasi, data harus terlebih dahulu ditransformasi menjadi distribusi gaussian (standar normal). Proses simulasi dengan DGM menggunakan change of support coefficient $(r)$ dan block gaussian semivariogram. Untuk menghitung change of support coefficient $(r)$ dan block gaussian semivariogram menggunakan subroutine atau script variog.m. Parameter yang dibutuhkan untuk menghitung change of support coefficient $(r)$ dan block gaussian semivariogram adalah block size, block discretization, dan model semivariogram dari data yang telah ditransformasi ke distribusi gaussian (Emery, 2009). Block size atau ukuran blok yang digunakan sama seperti spasi bor rata-rata di daerah penelitian. Untuk block discretization yang digunakan adalah $5 \times 5 \times 1$. Pembuatan block gaussian semivariogram dilakukan dengan arah omnidirectional.

Hasil atau output dari script variog.m adalah nilai change of support coefficient $(r), r, r v$, dan nilai $v\left(v, v^{\prime}\right)$. Nilai $r$ akan digunakan sebagai input untuk melakukan simulasi dengan metode DGM. Untuk nilai $r^{*}$ dan $r v$ tidak digunakan karena merupakan optional. Nilai $r\left(v, v^{\prime}\right)$ yang telah diperoleh selanjutnya dilakukan fitting variogram untuk mengetahui parameter-parameter variogram dari block gaussian semivariogram. Untuk block gaussian semivariogram dari masing-masing komoditas/mineral dapat dilihat pada Gambar 3.
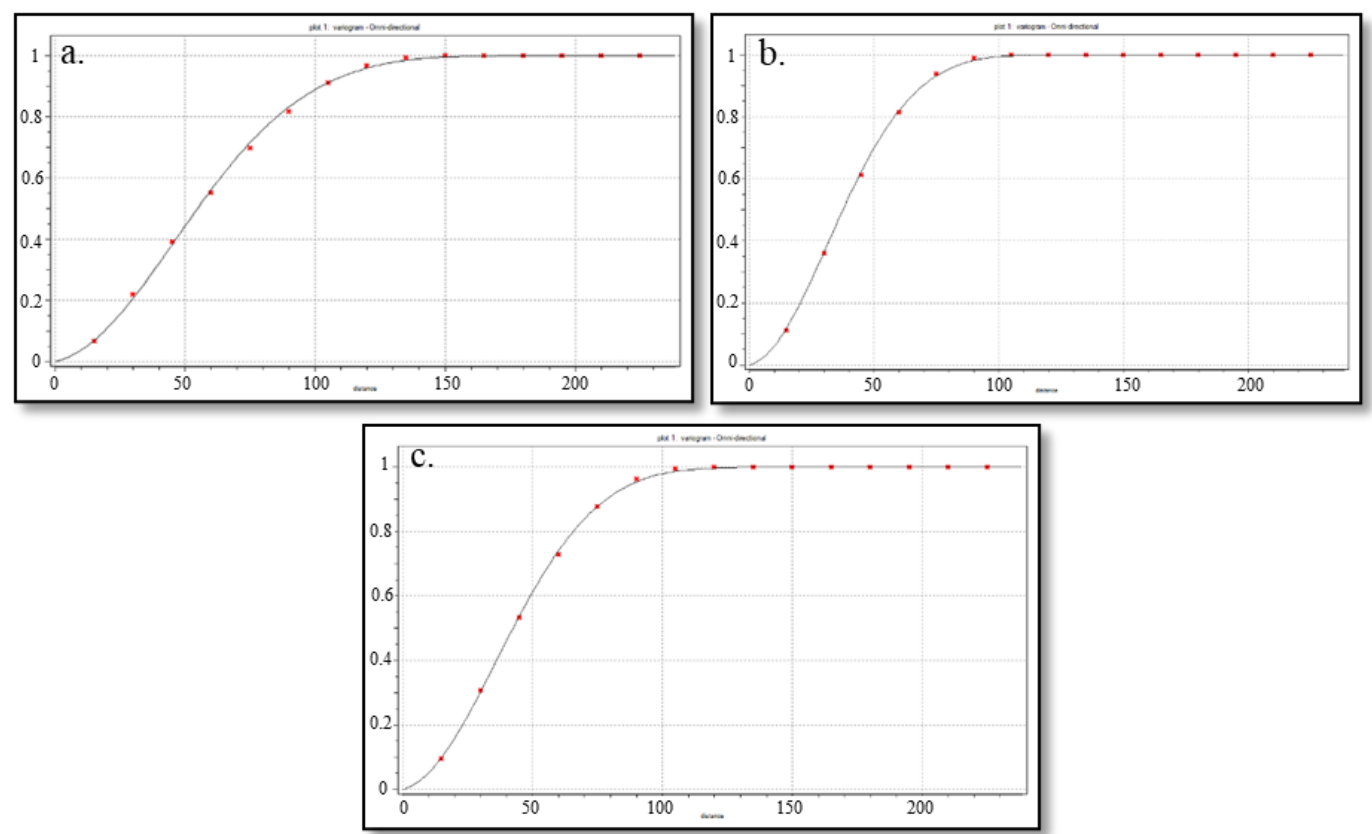

Gambar 3. Block gaussian semivariogram untuk: (a). Sn (timah), (b). IImenite+Rutile+Anatase, dan (c). Zircon 
Selanjutnya dilakukan proses simulasi dengan DGM menggunakan script blocktbsim.m untuk masingmasing komoditas/mineral. Simulasi dilakukan menggunakan Simple Kriging (SK) dengan jumlah realisasi adalah 100. Hasil atau output dari script blocktbsim.m adalah ASCII file dengan nilai hasil simulasi pada setiap blok simulasi per realisasinya yang telah di-back transform. Hasil simulasi dengan menggunakan DGM akan dicari nilai minimum dan maksimum dari 100 realisasi yang dihasilkan pada setiap blok simulasi untuk dibandingkan dengan hasil simulasi menggunakan SGS.

\section{HASIL DAN PEMBAHASAN}

Berdasarkan nilai coefficient of variation (CoV) pada Tabel 1. dapat dilihat secara statistik, komoditas/mineral yang paling bervariasi adalah monazite. Monazite memiliki nilai CoV sebesar 2.7929, sedangkan Sn (timah) memiliki nilai CoV sebesar 0.8989, ilmenite+rutile+anatase sebesar 0.7697, dan zircon sebesar 0.9606. MIT seperti zircon dan monazite secara statistik lebih bervariasi daripada Sn (timah). Selain itu, semua data dari masing-masing komoditas/mineral di Blok C menunjukkan nilai CoV yang $>0.5$. Hal ini menunjukkan semua data yang digunakan memiliki distribusi lognormal.

Secara spasial yang dapat dilihat pada Tabel 2. daerah pengaruh/range dari variogram untuk masing-masing komoditas/mineral berkisar antara 45 - $70 \mathrm{~m}$. Komoditas/mineral yang memiliki nilai daerah pengaruh tertinggi adalah Sn (timah) dengan nilai sebesar $70 \mathrm{~m}$. Hal menunjukkan Sn (timah) lebih homogen daripada MIT. MIT seperti ilmenite+rutile+anatase memiliki nilai daerah pengaruh sebesar $45 \mathrm{~m}$ dan zircon sebesar $60 \mathrm{~m}$.

Perbandingan antara hasil relative error atau GSEP dengan menggunakan GEV dan SGS untuk masingmasing komoditas/mineral dapat dilihat pada Gambar 4. Berdasarkan Gambar 4. dapat dilihat semua hasil relative error dengan menggunakan GEV less confidence jika dibandingkan dengan hasil relative error dengan menggunakan SGS. Mengacu pada Corrnah dkk. (2013), keterbatasan utama dari metode GEV adalah tidak efektif pada data dengan skewness yang terlalu tinggi dan adanya efek proporsional. Namun, hasil dari GEV dapat dikompromi (compromised) jika terdapat efek proporsional yang kuat (Cornah dkk., 2013).

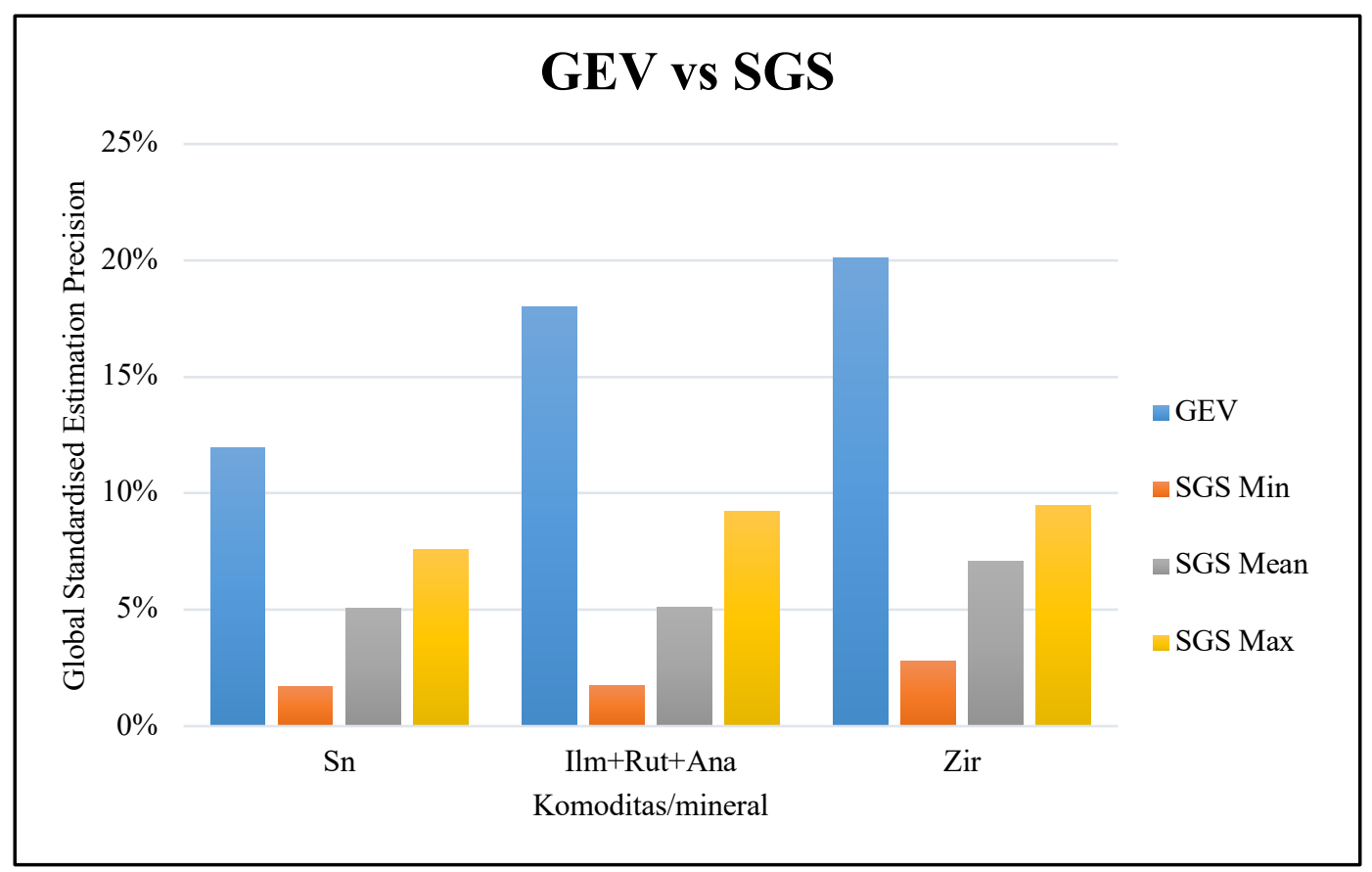

Gambar 4. Perbandingan nilai relative error atau GSEP antara GEV dan SGS untuk masing-masing komoditas/mineral

Efek proporsional sering dijumpai pada data yang mempunyai distribusi lognormal (Armstrong, 1998). Semua data yang digunakan pada penelitian ini memiliki distribusi lognormal yang dapat dilihat dari nilai $\mathrm{CoV}$ yang $>0.5$. Hal ini menunjukkan adanya gejala efek proporsional dari data-data yang digunakan. Transformasi data ke distribusi gaussian (standar normal) sebelum melakukan Gaussian Simulation efektif untuk menghilangkan efek proporsional pada data (Manchuk dkk., 2009). Oleh sebab itu, terdapat perbedaan antara hasil GEV dan 
Indonesian Mining Professionals Journal Volume 2, Nomor 2, November 2020 : 65 - 74

SGS yang dikarenakan adanya efek proporsional. Data yang digunakan pada metode GEV adalah data awal yang belum ditransformasi sehingga masih ada efek proporsional pada data tersebut. Sedangkan, data yang digunakan pada metode SGS adalah data yang telah ditransformasi ke distribusi gaussian yang efektif menghilangkan efek proporsional.

Perbandingan antara nilai minimum dan maksimum pada masing-masing blok hasil simulasi dengan menggunakan DGM dan SGS untuk masing-masing komoditas/mineral dapat dilihat pada Gambar 5. Berdasarkan Gambar 5. dari hasil perbandingan dapat dilihat terdapat komoditas/mineral yang menunjukkan hasil simulasi SGS dan DGM dengan pola yang hampir sama dan pola yang cukup berbeda. Pola yang hampir sama terdapat pada komoditas/mineral Sn (timah) dan ilmenite+rutile+anatase. Sedangkan pola yang berbeda terdapat pada komoditas/mineral zircon. Perbandingan hasil simulasi dengan DGM dan SGS dengan pola yang cukup berbeda disebabkan oleh pemusatan data yang merupakan bagian dari metode DGM, sehingga dapat menghasilkan beberapa perbedaan antara hasil DGM dan SGS (Cornah dkk., 2013).
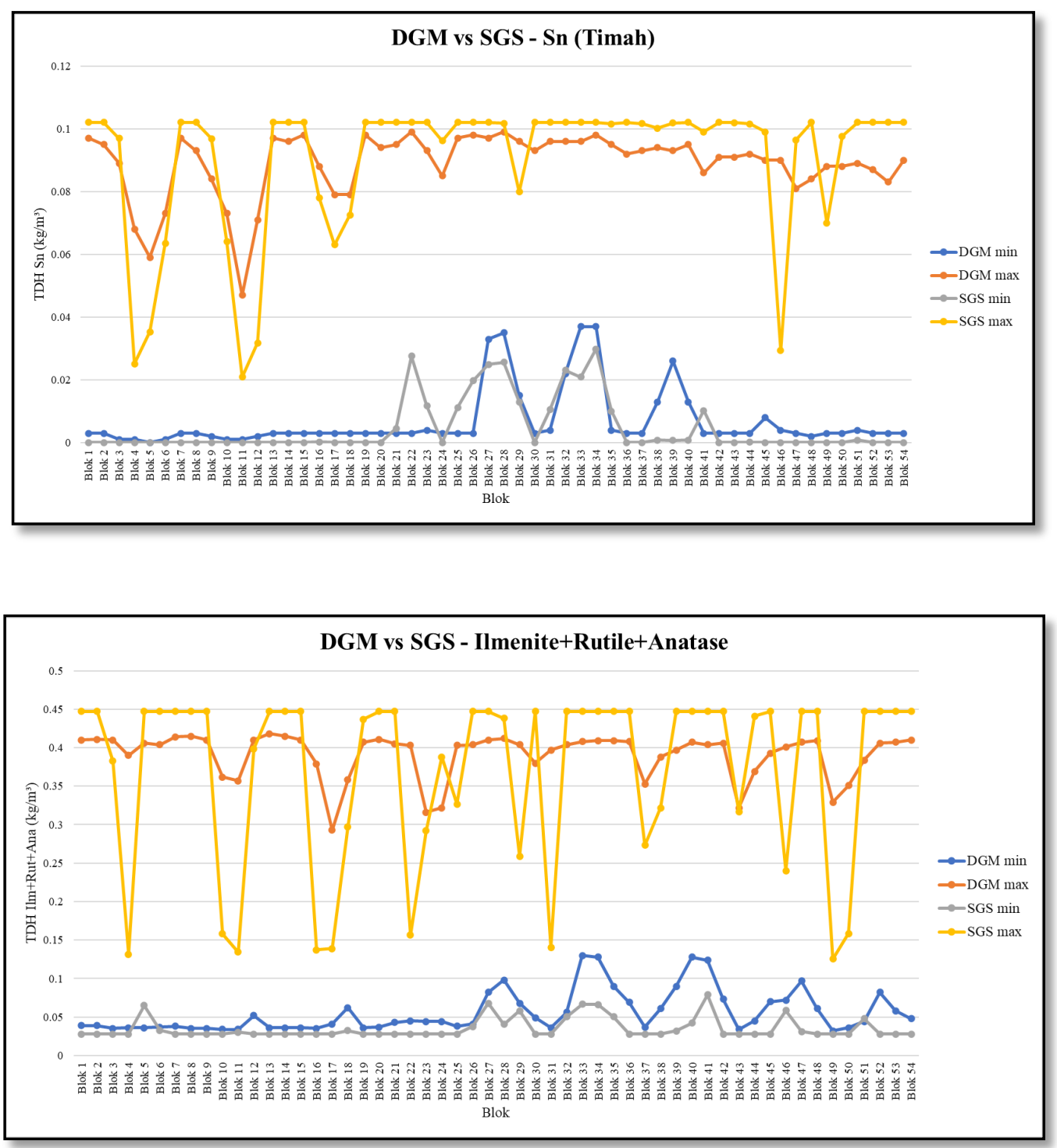


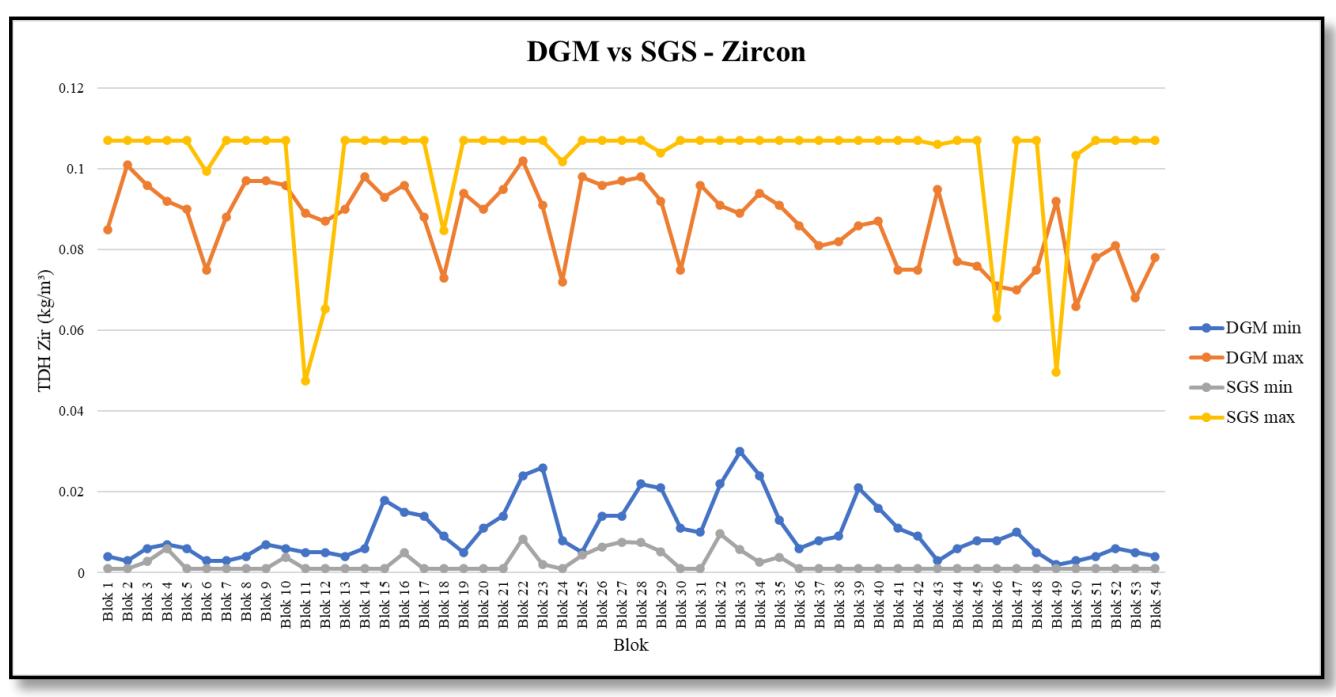

Gambar 5. Perbandingan pada setiap blok hasil simulasi dengan menggunakan DGM dan SGS untuk masingmasing komoditas/mineral

Selain itu, dari hasil perbandingan simulasi dengan menggunakan DGM dan SGS juga terlihat bahwa semua komoditas/mineral di daerah penelitian memiliki nilai minimum dari hasil DGM mayoritas lebih besar daripada nilai minimum dari hasil SGS dan nilai maksimum dari hasil DGM mayoritas menunjukkan hasil yang lebih kecil daripada nilai maksimum dari hasil SGS. Atau dengan kata lain hasil simulasi dengan menggunakan DGM lebih smooth jika dibandingkan dengan hasil simulasi dengan menggunakan SGS. Hal ini dikarenakan nilai change of support coefficient $(r)$ yang digunakan pada metode DGM. Jika nilai $r$ adalah 1 , maka tidak ada change of support dan fungsi transformasi dari block support sama seperti pada konversi tabel dari data asli ke gaussian yang dimasukkan sebagai salah satu input untuk simulasi dengan DGM dan begitupun sebaliknya, jika nilai $r$ adalah 0 fungsi transformasi block support menjadi konstan dan ditunjukkan oleh semua blok yang memiliki nilai yang sama (Emery, 2009). Untuk ilustrasi dari perbandingan beberapa nilai change of support coefficient $(r)$ terhadap fungsi transformasi dapat dilihat pada Gambar 6.

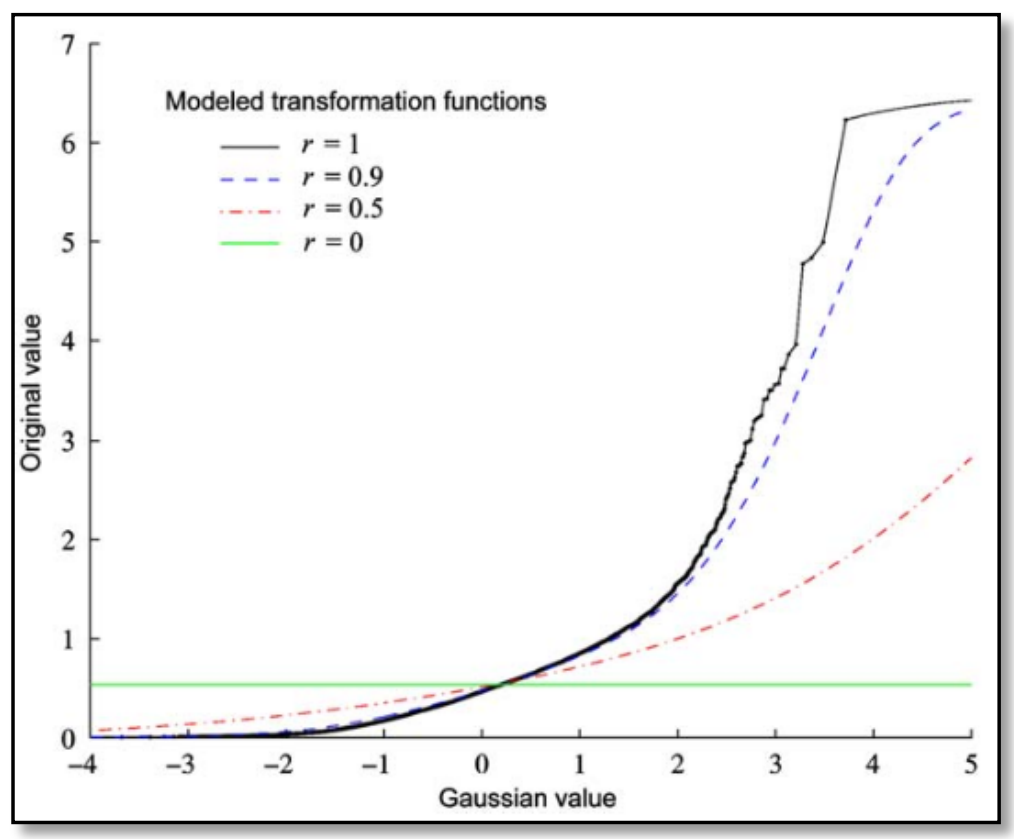

Gambar 6. Perbandingan beberapa nilai change of support coefficient (r) terhadap fungsi transformasi (Emery, 2009) 
Nilai change of support coefficient ( $r$ ) untuk masingmasing komoditas/mineral berkisar antara 0.72 0.89 . Sn (timah) dengan nilai change of support coefficient ( $r$ ) sebesar 0.89 , ilmenite+rutile+anatase sebesar 0.82 , dan zircon sebesar 0.72 . Sehingga nilai minimum dari hasil DGM mayoritas lebih besar daripada nilai minimum dari hasil SGS dan nilai maksimum dari hasil DGM mayoritas menunjukkan hasil yang lebih kecil daripada nilai maksimum dari hasil SGS.

\section{KESIMPULAN}

1. Hasil relative error dengan menggunakan GEV less confidence jika dibandingkan dengan hasil relative error dengan menggunakan SGS.

2. Hasil perbandingan simulasi dengan menggunakan SGS dan DGM menunjukkan pola yang hampir sama dan pola yang cukup berbeda.

3. Hasil simulasi dengan menggunakan DGM lebih smooth jika dibandingkan dengan hasil simulasi dengan menggunakan SGS.

\section{UCAPAN TERIMA KASIH}

Penulis mengucapkan terima kasih kepada PT Timah Tbk. yang telah memberikan dukungan dalam bentuk diskusi dan dataset dalam penelitian ini.

\section{DAFTAR PUSTAKA}

Armstrong, M. (1998): Basic Linear Geostatistic. Berlin: Springer.

Bertoli, O., Paul, A., Casley, Z., and Dunn, D. (2013): Geostatistical drillhole spacing analysis for coal resource classification in the Bowen Basin, Queensland. International Journal of Coal Geology, 112, 107-113.

Cornah, A., Vann, J., and Driver, I. (2013): Comparison of three geostatistical approaches to quantify the impact of drill spacing in resource confidence for a coal seam (with a case example from Moranbah North, Queensland, Australia). International Journal of Coal Geology, 112, 114-124.

Deraisme, J., Rivoirard, J., and Carrasco, P. (2008): Multivariate Uniform Conditioning and Block Simulations with Discrete Gaussian Model: Application to Chuquicamata Deposit. VIII International Geostatistics Congress, GEOSTATS 2008, Santiago, Chile.

Dixon, C. J. (1979): The Tin Deposits of the Kinta Valley Malaysia. Atlas of Economic Mineral Deposits, 2223.

Emery, X. (2009): Change-of-support models and computer programs for direct block-support simulation. Computer \& Geosciences, 35, 20472056.
Evans, A. M. (1993): Ore Geology and Industrial Minerals An Introduction. Third Edition. Blackwell Publishing.

Geovariances. (2016): Drill Hole Spacing Analysis. diperoleh melalui situs internet: https://www.geovariances.com/wpcontent/uploads/2016/07/geovarianceswhitepaper -dhsa.pdf. diakses pada tanggal 06 November 2019

Heriawan, M. N., and Koike, K. (2008): Uncertainty assesment of coal tonnage by spatial modeling of seam distribution and coal quality. International Journal of Coal Geology, 76, 217-226.

Heriawan, M. N., Pillayati, Widodo, L. E., and Widayat, A. H. (2020): Drill hole spacing optimization of nonstationary data for seam thickness and total sulfur: A case study of coal deposits at Balikpapan Formation, Kutai Basin, East Kalimantan. International Journal of Coal Geology, 223 (2020) 103466.

Madenoglu, S., Atalay, F., and Erpul, G (2020): Uncertainty assesment of soil erodibility by direct sequential Gaussian simulation (DSIM) in semiarid land uses. Soil \& Tillage Research, 204 (2020) 104731.

Manchuk, J. G., Leuangthong, O., and Deutsch, C. V. (2009): The Proportional Effect. Math Geosci (2009), 41, 799-816.

Ng, S. W. P., Whitehouse, M. J., Roselee, M. H., Teschner, C., Murtadha, S., Oliver, G. J. H., Ghani, A. A., and Chang, S. C. (2017): Late Triassic granites from Bangka, Indonesia: A continuation of the Main Range granite province of the South-East Asian Tin Belt. Journal of Asian Earth Sciences, 138 (2017), 548-561.

Paithankar, A., and Chatterjee, S. (2017): Grade and Tonnage Uncertainty Analysis of an African Copper Deposit Using Multiple-Point Geostatistics and Sequential Gaussian Simulation. Natural Resources Research

Purwadi, I., van der Werff, H. M. A., and Lievens, C. (2020): Targeting rare earth element bearing mine tailings on Bangka Island, Indonesia, with Sentinel-2 MSI. Int J Appl Earth Obs Geoinformation, 88 (2020) 102055.

Schwartz, M. O., Rajah, S. S., Askury, A. K., Putthapiban, P., and Djaswadi, S. (1995): The Southeast Asian Tin Bel. Earth-Science Reviews, 38 (1995), 96293.

Sinclair, A. J., and Blackwell, G. H. (2002): Applied Mineral Inventory Estimation. Camridge University Press.

Syafrizal, Amertho, S. D., Azwardi, I., Indriati, T., Nabilla, A. O., Suharjo, E. G. W., dan Hede, A. N. H. (2019): Karakterisasi Mineral Ikutan Timah pada Endapan Primer, Sekunder, dan Tailing di Bangka Selatan dan Belitung. Prosiding TPT XXVIII Perhapi 2019, 807-816.

Syafrizal, Pradana, A. S., Amertho, S. D., Azwardi, I., Heriawan, M. N., dan Hede, A. N. H. (2019): Studi Distribusi Mineral Ikutan Timah (MIT) untuk Mendukung Metoda Penanganan Sampel pada Kegiatan Eksplorasi. Prosiding TPT XXVIII Perhapi 2019, 797-806. 